\title{
New thinking in HIV prevention: an anthropological and epidemiological viewpoint
}

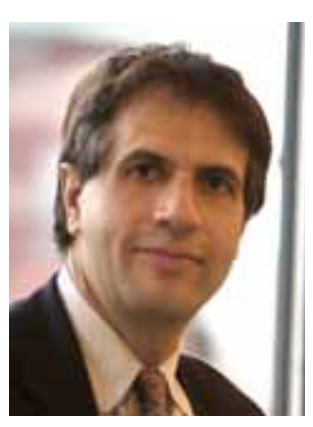

Danid T Halperin

$\mathrm{H}$ arvard U niversity School of Public Health, D epartment of Global $H$ ealth \& Population, $665 \mathrm{H}$ untington Avenue, Boston, M A 02115, USA Tel.: +1 617432 7388; Fax: +1 617432 6733; daniel_halperin@ harvard.edu

Prior to his current faculty position in the Department of Global Health and Population at the Harvard School of Public Health, Halperin served for over 5 years as the Senior HIV Prevention and Behavior Change Advisor at the USA Agency for International Development. Halperin has conducted epidemiological and ethnographic research for 30 years on a number of health and sociocultural issues in Latin America, sub-Saharan Africa and other developing regions. Since completing his doctoral training in medical and cultural anthropology at the University of California, Berkeley, in 1995, his work has mainly focused on the heterosexual transmission of HIV and other sexually transmitted infections. Most of Halperin's research and scientific publications have dealt with some of the previously more neglected HIV co-factors, such as concurrent sexual parther networks, lack of male circumcision, 'dry sex' practices, alcohol use and heterosexual anal intercourse. He has conducted field research and consultations over the years in a number of countries, including Brazil, South Africa, Botswana, Zimbabwe, Mozambique, Haiti, the Dominican Republic and Peru.

What is your research background? I have been carrying out research in developing countries for over 30 years. Much of that time has been spent in Latin America, mainly conducting qualitative research. I was originally trained as a medical anthropologist - I took a $\mathrm{PhD}$ in medical and cultural anthropology at Berkeley (CA, USA). I became increasingly interested in HIV/AIDS in the early- to mid-1990s, initially from a more qualitative and ethnographic viewpoint, then increasingly from an epidemiological perspective. M y doctoral and postdoctoral training and research has therefore enabled me to view public health problems from two different angles: the anthropological and the epidemiological.

What is the research history of the link between male circumcision \& HIV transmission?

The late Aaron J Fink wrote a letter to the $\mathrm{N}$ ew England Journal of M edicine in 1986, evidently the first time that the link between male circumcision and HIV transmission was put into print, at least in a major journal [1]. He was a clinician who had observed some sort of association. Shortly thereafter, the anthropologist Priscilla Reining noticed great variation in H IV prevalence amongst different regions of Africa. She was working in Tanzania looking at various ethnic communities. She was struck by the variability in H IV transmission between the different areas she visited; while some villages were devastated, others were left relatively unharmed.
This led to her collaboration with some demographers that resulted in a paper in the late 1980s in which they overlaid male circumcision with HIV transmission rates, demonstrating a very strong correlation [2]. Another important publication was about a cohort study conducted by a Canadian group that followed a group of Kenyan men who regularly visited prostitutes in $\mathrm{N}$ airobi [3]. They looked for a number of risk factors for HIV transmission but the one that, to their suprise, really leapt out from the data was circumcision. When confounding factors were controlled for, uncircumcised men were eighttimes more likely to contract H IV than circumcised men. This study was published in The Lancet and really started to make the wider scientific community more aware of the connection.

After this initial period of research, skepticism began to arise. $M$ any people suggested that the results were just ecological correlations arising from confounding factors. For example, it was suggested that circumcised communities engage in different sexual behavior patterns compared with uncircumcised communities. Researchers from the London School of $\mathrm{H}$ ygiene and Tropical Medicine (UK) and their Tanzanian collaborators conducted a large study looking at a cross-sectional proportion (around 5000-10,000 participants) of the population of M wanza, Tanzania [4]. Initially the raw data seemed to show no significant relationship between circumcision and HIV status, and this finding may have helped dampen interest for some years in pursuing the circumcision factor. 
In fact, later on, members of that same London School research group became some of the main documenters of the circumcision-H IV evidence.

How did you become involved in the topic?

Around 15 years ago, when examining data on HIV prevalence levels in Africa and South-East Asia, I was struck by the enormous heterogeneity. It was not immediately obvious why this was so, as none of the traditional causes of variability in HIV transmission could fully explain the pattern. So I began to think there was some sort of $X$-factor, which had so far been overlooked. That was when I came across male circumcision, in reviews by people like the Caldwells and Stephen M oses $[5,6]$. By this time (the mid- to late-1990s), dozens of studies had been carried out, looking at various risk factors for H IV; some surveys asked whether the participant was circumcised as a demographic variable. Circumcision was often not mentioned or at least emphasized in the text of these papers, but when you look at the data they collected the link is there. This led to our paper, with fellow anthropologist and epidemiologist Robert Bailey (U niversity of Illinois, Chicago, USA), in the The Lancet in 1999, entitled 'M ale circumcision and HIV infection: 10 years and counting' because it was 10 years since the Nairobi study was published in the same journal [7].

The paper generated some interest, although many dismissed the findings. Around that time, Richard $\mathrm{H}$ ayes along with $\mathrm{Helen}$ Weiss of the London School revisited their M wanza data, which eventually resulted in a systematic metaanalysis (by Weiss et al.) published in the journal AID S in 2000 [8]. When they performed a multivariant analysis of the data a significant correlation between H IV transmission and lack of male circumcision emerged.

A lot of criticisms have been aimed at your, and others, work on the link between male circumcision and HIV transmission. How would you address concerns over large survey studies that show no link?

Some large demographic and health surveys in Africa, in a similar way to the M wanza raw data, suggest that male circumcision has no effect on, or in a couple of cases even increases, the occurrence of H IV transmission. H owever, the argument that is made based on this kind of data is rather weak. So many potential confounding factors are ignored; for instance, in many parts of
Africa circumcised men tend to be somewhat wealthier and more urban (and hence have a higher risk of becoming HIV-infected) than uncircumcised men, so in the univariate analysis it might appear that circumcision is not protective. Or, in some parts of Africa (Lesotho, for example), culturally circumcision refers to the traditional practice of going through male initiation rites, which often may not actually involve full (or occasionally even any) physical removal of the foreskin [101]. These sorts of confounders can really water down the data. If you take the data from these demographic studies and, for example, look for a relationship between condom use and HIV transmission, usually no significant correlation is found. But no serious scientist would suggest that in reality condoms have no effect on HIV transmission. Therefore, such large cross-sectional studies, while useful in some regards, should not be held up as epidemiologically important measures of the 'true' biological effect of circumcision. Certainly, the findings of the randomized, clinical trials are ultimately much more crucial.

And concerns over the methodology of the circumcision trials?

The trials were performed in the same way as any pharmaceutical, vaccine or microbicide trial; these were controlled trials, where both arms received the same level of sex education and condoms, and so on. All three trials were halted prematurely by their ethics boards because in each case the intervention group had considerably lower rates of HIV acquisition (50-75\% lower, depending on the measure used) than the control arm [9]. C riticism of the early halting of the trials has been previously addressed by us (this year in the journal AID S [10]). Rather than weakening, in one or two of the trials the effect was actually getting stronger over time. Some people have also alleged that there has not been any subsequent follow-up of these study populations, but that is not true, and although follow-up is underway, that certainly does not mean we cannot begin using circumcision to prevent HIV infection now. If we had to wait 10 years for a follow-up study for every treatment and prophylactic you would wipe out half the drugs in a pharmacy.

It has also been suggested that the financial costs of implementing male circumcision would be too high? Vaccine research receives vast sums of money, coporate sponsorship, and so on, all based on the 
hope that one day these products, which are still in the early phases of development, will pan out. By contrast, some of us have proposed the creation of an 'International Male Circumcision Alliance' to coordinate educational and research efforts to use circumcision for HIV prevention and male reproductive health [11]. The proposed boards of directors and scientific advisors are comprised of many of the leading HIV scientists and professionals from Africa and around the world, and yet after a year of trying we still cannot find any foundation or other organization to donate the approximately US\$300,000 needed to open an office (in Africa) to help implement this intervention that is not merely hypothetical, but already proven to work.

The US government currently spends nearly US\$1 billion per year on research into a potential HIV vaccine. The same U S\$1 billion, spread over 5 years, would easily be enough to implement male circumcision on a massive scale in Africa. In many countries now men are being turned away from public facilities that provide (on a very limited basis) circumcision. In fact, male circumcision does not require any or much active promotion in the places in Africa where it is most needed, as there is al ready considerable demand (and 'unmet need') for the service. We simply need to make the service safe, available and affordable for those who al ready or will want it.

Similar criticisms and doubts were leveled at antiretrovirals - that it would cost too much to implement them on a large scale in Africa - but they are now being much more widely used, and if anything circumcision is arguably easier to provide. Certainly there are less issues around sustainability in the longer run (since most of the demand will come just in the next few years). Some of the most economically deprived and unstable countries in the world al ready have near-universal population 'coverage' of male circumcision. It is often believed that the countries most affected by H IV/AID S are very poor, yet many of the countries with the highest HIV prevalence - for example, South Africa and Botswana - are far from poor; in fact, they already have most of the health facilities and infrastructure needed to scale-up this relatively very simple surgical procedure. There are now a number of published studies that look at the acceptability, feasibility, cost and potential complications of implementing mass circumcision programs in Africa [12-17].
Where do you see your research heading in the next five or so years? I have generally been drawn to more neglected areas of research. M ost of my research has been on behavior change and other aspects of HIV prevention, and I will probably continue to work on this to some extent. I have also been looking at mother-to-child-transmission of HIV, specifically the importance of promoting exclusive breastfeeding to reduce HIV transmission, as well as generally improving the health outcomes for children and mothers [18]. I have just completed a paper of an epidemiological study looking at the risk of anal sex in heterosexual women, which is a rather common practice in various countries, such as Brazil [19]. It was first presented at the AID S Conference in Spain 6 years ago and unfortunately it has taken us this long to get around to finishing it. We found that receptive anal sex is at least ten-times riskier, per act, than receptive vaginal sex.

I would also like to move onto other topics besides H IV. It has been my near-exclusive focus for the last 15 years. Although HIV/AIDS is a big problem, it is obviously not the only one in the developing world; however, it seems to receive the vast majority of funding. Other diseases that also kill millions get nowhere near the attention or resources that HIV does now [20].

For me, the number one issue - although it is going to sound horribly cliché these days - is global warming. If HIV/AIDS is a two-storey building, climate change is a huge sky scraper, it towers over everything else. In fact, I think the situations with HIV and global warming are, in a way, mirror images of one another. When I first became involved in H IV a lot of very dire predictions were made about its future. Although it has devastated a number of African countries it has not turned out to be as disastrous globally as many had predicted. Global warming is the reverse. Until very recently it has been largely ignored or dismissed, at our tremendous peril, I think. I do not know how an HIV expert becomes involved in climate change, but when I look at my young children I do not worry that in 20 years they will die of AIDS, although of course that is possible, what I really worry about are the impacts of global warming. The possibility of many of the world's largest cities being underwater and perhaps many millions of people eventually dying as a result is certainly a "health issue' to me! 
Finally, it is just over a quarter of a century since the discovery of HIV as the causative agent of AIDS. What do you consider to have been our major medical achievements in the field \& what are your hopes for the next 25 years of HIV/AIDS research? A little over a year ago the W H O and UN AIDS held a large meeting in Switzerland. The D irector of the HIV Program at WHO, Kevin de Cock, gave the closing talk and prepared a few slides outlining his view of the major landmarks in the AIDS epidemic. They included: the discovery of the HIV virus, the development of antiretroviral medicines, the introduction of triple therapy and the three male circumcision trials, and I would agree with him. I would like to also include the growing recognition of the effect of behavioral change - especially partner reduction - on H IV decline in countries such as $\mathrm{U}$ ganda, Kenya and Zimbabwe. This increasingly consistent pattern has been identified by a number of researchers in the last few years [21-27,102]. While perhaps not yet universally accepted, I think the evidence is pretty clear by now.

As for the future, I certainly hope we will have a vaccine one day, although it has seen some serious setbacks recently. I also think we will have seen circumcision becoming much more widely available in southern Africa, as well as behavior change programs coming to fruition. All of these developments should result in a considerable lowering of HIV transmission at the population level - for women as well as for men.

Financial \& competing interests disclosure The author has no relevant affiliations or financial involve ment with any organization or entity with a financial interet in or financial conflict with the subject matter or materials discussed in the manuscript. This includes employment, consultancies, honoraria, stock ownership or options, expert testimony, grants or patents received or pending, or royalties.

\section{Bibliography}

1. Fink AJ : A possible explanation for heterosexual male infection with AIDS. N. Engl. J. M ed. 315, 1167 (1986).

2. Bongaarts J, Reining $P$, Way $P, C$ onant $F$ : The relationship between male circumcision and H IV infection in African populations. AIDS 3(6), 373-377 (1989).

3. Cameron DW, Simonsen JN, D 'C osta LJ et al.: Female to male transmission of human immunodeficiency virus type 1: risk factors for seroconversion in men. Lancet 2 , 403-407 (1989).

4. Barongo LR, Borgdorff M W, M osha FF et al.: The epidemiology of H IV-1 infection in urban areas, roadside settlements and rural villages in M wanza Region, Tanzania. AID S 6, 1521-1528 (1992).

5. Caldwell JC, Caldwell P: The African AIDS epidemic. Sci. Am. 274, 62-63, 66-68 (1996).

6. M oses S, Bailey RC, Ronald AR: M ale circumcision: assessment of health risks and benefits. Sex Transm. Inf. 74, 368-373 (1998).

7. $H$ al perin DT, Bailey RC: $M$ ale circumcision and H IV infection: 10 years and counting. Lancet 354, 1813-1815 (1999).

8. Weiss H A, Q uigley M A, H ayes RJ: $M$ ale circumcision and risk of HIV infection in sub-Saharan Africa: a systematic review and meta-analysis. AID S 14, 2361-2370 (2000).
9. Shelton J: Estimated protection too conservative. Plos M ed. 3, e65 (2006).

10. Weiss $H A, H$ alperin DT, Bailey RC, $H$ ayes $R$, Schmid $G, H$ ankins $C$ : $M$ ale circumcision for HIV prevention: from evidence to action? AIDS 22, 567-574 (2008).

11. Klausner JD, Wamai R, Bowa K, Agot K, Kagimba J, $H$ alperin DT: Is male circumcision as good as the HIV vaccine we've been waiting for? Future H IV Ther. 2 , 1-7 (2008).

12. Westercamp N, Bailey RC: Acceptability of male circumcision for prevention of HIV/AIDS in sub-Saharan Africa: a review. AID S Behav. 11, 341-355 (2007).

13. Williams BG, Lloyd-Smith JO, Gouws E et al.: The potential impact of male circumcision on H IV in sub-Saharan Africa. PLOS M ed. 3, e262 (2006).

14. N agelkerke $\mathrm{N}$ J, M oses S, de V las SJ, Bailey RC: M odelling the public health impact of male circumcision for H IV prevention in high prevalence areas in Africa. BM C Infect. Dis. 7, 16 (2007).

15. Kahn JG, M arseille E, Auvert B: Cost-effectiveness of male circumcision for HIV prevention in a South African setting. PLOS M ed. 3, e517 (2006).

16. Agot $K E$, Kiarie JN, $N$ guyen $H Q$, O dhiambo JO , O nyango TM , Weiss N S: $M$ ale circumcision in Siaya and Bondo
D istricts, Kenya: prospective cohort study to assess behavioral disinhibition following circumcision. J. Acquir. Immune D efic. Syndr. 44, 66-70 (2007).

17. Gray RH, Li X, Kigozi $G$ et al.: The impact of male circumcision on HIV incidence and cost per infection prevented: a stochastic simulation model from Rakai, U ganda. AIDS 21, 845-850 (2007).

18. H alperin DT: Breastfeeding and H IV transmission: the realities may be much more complex than 'breast vs. bottle.' G lobal AID SLink 58, 8-10 (1999).

19. $\mathrm{H}$ alperin $\mathrm{DT}$ : $\mathrm{H}$ eterosexual anal intercourse: prevalence, cultural factors, and HIV infection and other health risks. AID S Patient Care ST D S 13, 717-730 (1999).

20. H alperin DT. Putting a plague in perspective. N ew York Times, 1st January (2008).

21. Potts $M, H$ alperin $D T$, Kirby $D$ et al.: Reassessing H IV prevention. Science 320, 749-750 (2008).

22. Stoneburner RL, Low-Beer D: Populationlevel HIV declines and behavioral risk avoidance in U ganda. Science 304, 714- 718 (2004).

23. Shelton JD, $H$ alperin DT, $N$ antulya V, Potts M, Gayle H D, H olmes KK: Partner reduction is crucial for balanced ' $A B C$ ' approach to H IV prevention. BM J 328, 891-893 (2004). 
24. Green EC, H alperin DT, N antulya V, $\mathrm{H}$ ogle JA: U ganda's H IV prevention success: the role of sexual behavior change and the national response. AIDS Behav. 10, 335-346 (2006).

25. Kirby $D$ : The changes in sexual behavior leading to the decline of H IV prevalence in $U$ ganda - confirmation from multiple sources of evidence. Sex. Trans. Infections (2008) (In Press)

26. Shelton D: Ten myths and one truth about generalised HIV epidemics. Lancet 370, 1809-1811 (2007).

27. H alperin DT, Epstein $\mathrm{H}$ : Why is H IV prevalence so severe in southern Africa? The role of multiple concurrent partnerships and lack of male circumcision: implications for AID S prevention. South African J. HIV M ed. 26, 19-25 (2007).

\section{Websites}

101. WH O/U N AID S. M alecircumcision: global trends and determinants of prevalence, safety and acceptability (2008). www.who.int/hiv/topics/malecircumcision/] C1320_M aleC ircumcision_Final_U N AIDS .pdf

102. Southern African D evelopment Community. Expert think tank meeting on H IV prevention in high-prevalence countries in southern Africa. Report. (2006). www.sadc.int/downloads/news/SAD C PrevR eport.pdf
Affiliation

- Daniel Halperin

$\mathrm{H}$ arvard U niversity School of Public $\mathrm{H}$ ealth, D epartment of Global H ealth \& Population, $665 \mathrm{H}$ untington Avenue, Boston,

M A 02115, USA

Tel.: +1 6174327388 ;

Fax: +1 617432 6733;

danie__halperin@harvard.edu 